\title{
The small farm: It's innovative and persistent in a changing world
}

\author{
Desmond A. Jolly
}

\begin{abstract}
Small farms contribute new crops and new practices to agricultural production, and to achieve efficiency, some use resources as successfully as do much larger operations. Small farms, it is hoped, will continue their vital role in U.S. agriculture - even as major changes occur today in international trade.
\end{abstract}

For many, small farming evokes the romance of self-sufficiency, the cornerstone of American popular culture for centuries. Small farmers - family farmers - embody sound family and community values. Notions of the small farm may be romanticized, but small farming generally gains a sympathetic response.

On the other hand, some perceive small farming as wasteful, an irrational allocation of resources. The assumption is that human needs and wants for food, fibre and agricultural raw materials are urgent and constantly growing. Such resources as land, labor, capital and other inputs are, if not fixed, relatively scarce. Consequently, the enterprises utilizing these resources most efficiently are seen as having greater benefit to society; because they use less, they free resources for other production. This paradigm has informed agricultural policies since the depression of the 1930s.

However, according to the Census of Agriculture - California, the number of farms in size classes $\$ 10,000-\$ 24,999$, $\$ 25,000-\$ 49,999$ and $\$ 50,000-\$ 99,999$ increased between 1982 and 1987 censuses by $8.9,8.3$ and $7.3 \%$, respectively. (See table 1.) Not-so-small farms, those grossing between $\$ 100,000$ and $\$ 499,999$, grew by $7.1 \%$; large farms, those with more than $\$ 500,000$ in annual sales, increased by $13 \%$.
Many small-scale farms are operated by persons who farm by choice, but not necessarily because they expect to earn their entire livelihoods from farming. Others farm because it is a way to achieve quasi-independence from urban centers. Still others have inherited land and a lifestyle from their families. Whatever the motives, small farms are persisting in the production of food and fibre.

Now that world trade barriers are tumbling (through the North American Free Trade Agreement and the Uruguay Round of the General Agreements on Trade and Tariffs) increasing global competition will necessitate greater economic efficiency. Any class of farmers that is inefficient will risk elimination from the industry. Many have argued for large-scale agricultural operations. Thus, we may ask: Do smallscale farmers have a significant role in 21st century U.S. agriculture? Will inefficiency result in their elimination? What are their contributions to agricultural production?

\section{Persistence of small farms}

Between 1954 and 1987, the number of U.S. farms declined from $4,782,416$ to $2,087,759$ and average farm size nearly doubled from 242 to 462 acres. Nonetheless, in 1987 there still remained 218,050 farms with annual sales of between $\$ 50,000$ and $\$ 100,000$ and 263,696 farms grossing between $\$ 100,000$ and $\$ 499,999$. The line drawn between the small and large farm is somewhat arbitrary, but we would include as small farms those with sales up to $\$ 500,000$ per year. In terms of organizational structure, family or individually owned units account for $1,809,324$ out of the 2,087,759 farms in the U.S.

In California, the number of farms declined $32 \%$, from 123,075 in 1954 to 83,217 in 1987. Average farm size increased from 307 to 368 acres. Still, $17 \%$ of California's farms had sales of between $\$ 50,000$ and $\$ 249,999$ in $1987 ; 10 \%$ sold between $\$ 250,000$ and $\$ 499,999$. At the lower end, $22.7 \%$ of California's farms had sales of between $\$ 10,000$ and $\$ 50,000 ; 48.5 \%$ had sales of less than $\$ 10,000$. The $6.8 \%$ of California's farms with sales of more than $\$ 500,000$ accounted for $74.1 \%$ of the value of farm products sold.

The size of California farms reflects the land tenure system established by Spanish settlers; the tenure structure superimposed on that earlier system by the U.S. government through its own land grants, and other complex factors including access to credit, water, government subsidies, research and extension.

\section{How efficient are small farms?}

There is increasing recognition that earlier concepts about the efficiency of large farms versus small farms tended to favor large operations. Figure 1 reflects the benefit of recent empirical information on efficiency and size. The UC Giannini Foundation report, Farm Size Relationships, with an Emphasis on California, indicates that small farming units do not necessarily waste resources, but observes that even the continued existence of these "efficient" farms may not be justified because the incomes of the farm operators may still be inadequate when compared with incomes they could earn in alternative employment. If alternative employment opportunities do exist and these farm operators choose to transfer their employment to these alternatives, one could argue that society may be better off. If, however, alternative opportunities are scarce, the continued existence of these farms is economically rational.

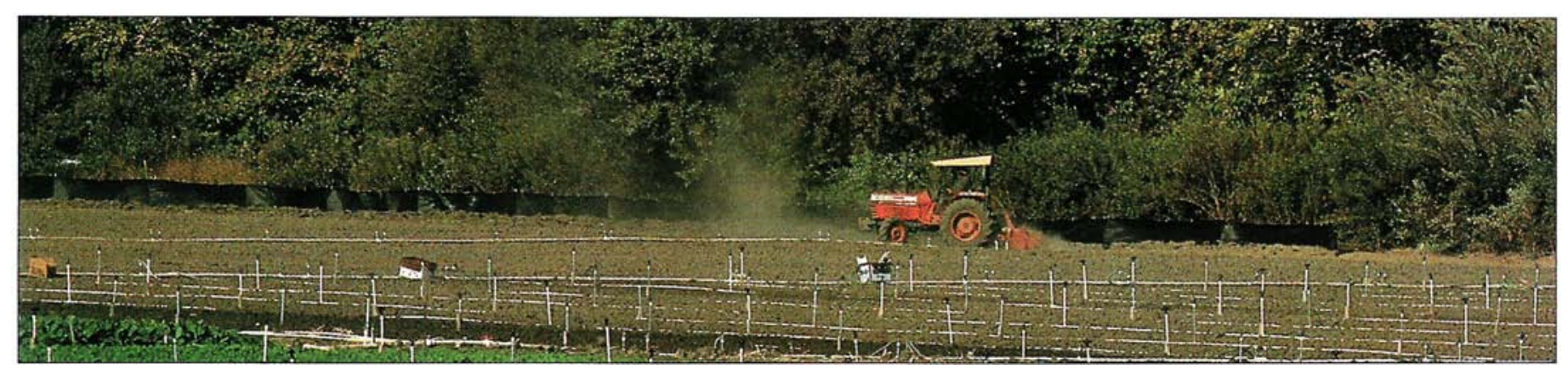




\begin{tabular}{|c|c|c|c|c|c|}
\hline Categories & 1987 & $\begin{array}{l}\text { Increase or } \\
\text { decrease } \\
\text { from } 1982\end{array}$ & 1982 & $\begin{array}{l}\text { Increase or } \\
\text { decrease } \\
\text { from } 1978\end{array}$ & 1978 \\
\hline & & $\%$ & & $\%$ & \\
\hline No. of farms & 83,217 & 0.009 & 82,463 & 12.7 & 73,194 \\
\hline Total farm acreage & $30,598,178$ & $(4.8)$ & $32,156,894$ & $(1.7)$ & $32,727,202$ \\
\hline Average size & 368 & $(5.6)$ & 390 & $(12.8)$ & 447 \\
\hline \multicolumn{6}{|l|}{ Farms by value of sales: } \\
\hline$<\$ 2,500$ & 23,187 & $(9.1)$ & 25,513 & 38.0 & 18,494 \\
\hline$\$ 2,500-\quad 4,999$ & 8,661 & (1.8) & 8,817 & 6.0 & 8,306 \\
\hline $5,000-9,999$ & 8,521 & $(0.0)$ & 8,515 & 3.2 & 8,253 \\
\hline $10,000-24,999$ & 11,028 & 8.3 & 10,178 & (2.7) & 10,460 \\
\hline $25,000-49,999$ & 7,863 & 8.9 & 7,218 & $(4.0)$ & 7,519 \\
\hline $50,000-99,999$ & 6,895 & 7.3 & 6,423 & (2.6) & 6,593 \\
\hline $100,000-499,999$ & 11,430 & 7.1 & 10,675 & 9.0 & 9,797 \\
\hline $500,000+$ & 5,641 & 13.0 & 4,990 & 38.6 & 3,600 \\
\hline \multicolumn{6}{|l|}{ Type of organization: } \\
\hline Individual or family & 64,929 & & 65,492 & & 57,916 \\
\hline Partnership & 12,127 & & 11,360 & & 10,815 \\
\hline Corporation & 5,367 & & 4,849 & & 3,871 \\
\hline \multicolumn{6}{|c|}{ Operator days worked off the farm: } \\
\hline None & 32,051 & & 29,641 & & 29,135 \\
\hline 200 or more & 30,948 & & 31,587 & & 27,140 \\
\hline \multicolumn{6}{|c|}{ Operator by principal occupation: } \\
\hline Farming & 41,906 & & 40,633 & & 38,060 \\
\hline Other & 41,311 & & 41,830 & & 35,134 \\
\hline Average age of operator & 53.6 & & 51.8 & & 51.3 \\
\hline
\end{tabular}

Source: Bureau of the Census, 1987 Census of Agriculture-California.

TABLE 2. Gains and losses by farm size in California, $1987^{\star}$

\begin{tabular}{lrrr}
\hline \hline Item & All farms & $\begin{array}{r}\text { Farms w/sales } \\
\text { of }>\$ 10,000\end{array}$ & $\begin{array}{r}\text { Farms w/sales } \\
\text { of }<\$ 10,000\end{array}$ \\
\hline Number of farms & 83,210 & 42,816 & 40,394 \\
Farms with net gainst (no.) & 42,252 & 33,025 & 9,227 \\
Aggregate gain $\$ 1,000)$ & $\$ 3,266,561$ & $\$ 3,249,754$ & $\$ 16,807$ \\
Average gain $(\$)$ & $\$ 77,311$ & $\$ 98,403$ & $\$ 1,822$ \\
Farms with net losses (no.) & 40,958 & 9,791 & 31,167 \\
Aggregate loss $\$ 1,000)$ & $\$ 339,282$ & $\$ 183,606$ & $\$ 155,676$ \\
Average loss $(\$)$ & $\$ 8,284$ & $\$ 18,753$ & $\$ 4,995$ \\
Number of farms with gain of: & & & \\
Less than $\$ 1,000$ (no.) & 5,048 & 1,192 & 3,856 \\
$\$ 1,000$ to $\$ 4,999$ (no.) & 9,002 & 4,327 & 4,675 \\
$\$ 5,000$ to $\$ 9,999$ (no.) & 5,152 & 4,456 & 696 \\
$\$ 10,000$ to $\$ 24,999$ (no.) & 7,211 & 7,211 & - \\
$\$ 25,000$ to $\$ 49,999$ (no.) & 5,281 & 5,281 & - \\
$\$ 50,000$ or more (no.) & 10,558 & 10,558 & \\
Number of farms with loss of: & & & 5,491 \\
Less than $\$ 1,000$ (no.) & 6,421 & 930 & 15,432 \\
$\$ 1,000$ to $\$ 4,999$ (no.) & 18,094 & 2,662 & 3,667 \\
$\$ 5,000$ to $\$ 9,999$ (no.) & 8,886 & 2,219 & 381 \\
$\$ 10,000$ to $\$ 24,999$ (no.) & 5,502 & 2,395 & 89 \\
$\$ 25,000$ to $\$ 49,999$ (no.) & 1,310 & 929 & \\
$\$ 50,000$ or more (no.) & 745 & 656 & \\
\hline
\end{tabular}

"Data are based on a sample of farms.

tFarms with total production expenses equal to market value of agricultural products sold are included as farms with gains of less than $\$ 1,000$.

Adapted from 1987 Census of Agriculture-California.

A study on Midwest farming systems found that many farms that sold between $\$ 25,000$ and $\$ 100,000$ worth of wheat had costs (per dollar of sales) that matched or were lower than costs of farms with more than $\$ 100,000$ in sales (fig. 2). This and other studies led the Congressional Budget Office to conclude in 1986 that the efficiency argument for providing subsidies and other noncash support to large farms was no longer defensible.

\section{Risk and viability}

Small farms are subject to production and marketing risks. Some small farms are overcapitalized; others are undercapitalized. Some have a good supply of household labor; others rely on hired labor.
Some are well situated vis-a-vis market outlets; others are relatively remote. These factors, and more, affect prospects for economic viability. The net effects are reflected in changes in farm numbers over various census periods. As table 1 indicates, farms in the smallest and largest size classes increased $38 \%$ between 1978 and 1982 , but farms with between $\$ 10,000$ and $\$ 100,000$ annual sales declined in number by 2.6 to $4 \%$. Farms with $\$ 100,000$ to $\$ 500,000$ in sales increased $9 \%$.

Between the 1982 and 1987 censuses, however, all size classes increased, with the exception of those with less than $\$ 5,000$ in annual sales. The smallest category, less than $\$ 2,500$ of sales, declined $9.1 \%$.

Table 2 shows the distribution of gains and losses of farms as reported by the 1987 Census of Agriculture - California. They indicate substantial variations in economic performance. Of farms with sales exceeding $\$ 10,000,77 \%(33,025)$ report positive economic returns - 10,558 with net cash returns of more than $\$ 50,000,22,467$ with returns of $\$ 49,999$ or less. The remaining $23 \%(9,791)$ report losses averaging $\$ 18,753$. For farms with sales under $\$ 10,000$, the percentages are reversed: $23 \%(9,791)$ showed average profits of $\$ 1,822$ per farm while $77 \%(31,167)$ report losses averaging $\$ 4,995$.

Successful small farms maintain economic viability by: (1) employing used instead of new equipment; (2) relying on contractors to carry out many capital-intensive activities; (3) producing specialty products for small, but remunerative markets; (4) utilizing diverse marketing outlets; (5) searching out and using information to reduce production and market risk, and (6) diversifying their sources of earnings, including off-farm income sources. Off-farm employment is often taken as evidence of lack of viability. However, the typical U.S. household has at least two sources of income, and big businesses diversify to achieve corporate objectives. Thus, the effort to increase household income with nonfarm income does not necessarily indicate weakness. It could as easily be perceived as bringing resilience to the small farm sector.

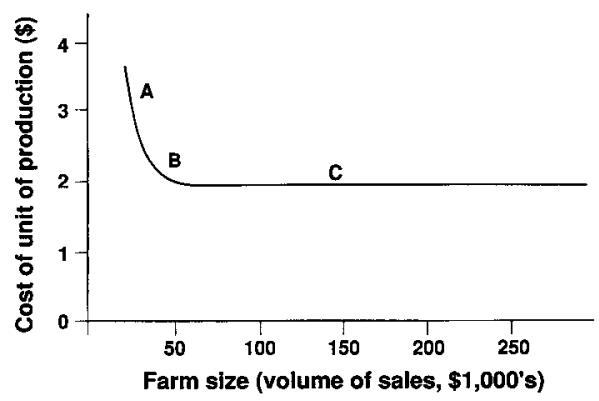

Fig. 1. Standard view of economies of size. 


\section{Other impacts}

The notion that a smaller, more diversified farming structure contributes to a more resilient and dynamic community is supported by empirical studies. For example, one study using the 1978 and 1982 censuses of agriculture identified the percentage of farms in the U.S. with gross 1982 sales of less than $\$ 40,000$. "Smallfarm" counties were defined as those where $88 \%$ or more of farms reported sales of less than $\$ 40,000$. "Large-farm" counties were defined as those where less then $59 \%$ of the farms reported sales under $\$ 40,000$. "Small-farm" counties were concentrated in the South and Southeast as well as in upper parts of the Great Lakes states. Large-farm counties were predominantly in the northern and southern Great Plains, lower parts of the Great Lakes states, in the Mississippi Delta and in scattered areas of the East and West. Large-farm counties were characterized by low population densities, few nonfarm job opportunities, grain farming, and high per capita income.

The large and small counties were compared on a number of performance measures. Comparing data from the 1978 and 1982 censuses, it was found that income per capita was higher $(\$ 9,807)$ in large-farm counties (see table 3), than in small-farm counties $(\$ 8,261)$, but in smallfarm counties, total employment increased by $17.4 \%$ between 1975 and 1982, compared with $6.1 \%$ in large-farm counties. Nonfarm employment grew by $20.8 \%$ in the small-farm counties compared with $10.2 \%$ in the large-farm counties. Manufacturing employment grew at comparable rates, but service employment in the small-farm counties grew at more than double the rate at which it grew in the large-farm counties. Because the smallfarm counties enjoyed a more diversified economic structure, they were more resilient to economic stresses and more capable of funding public services such as education.

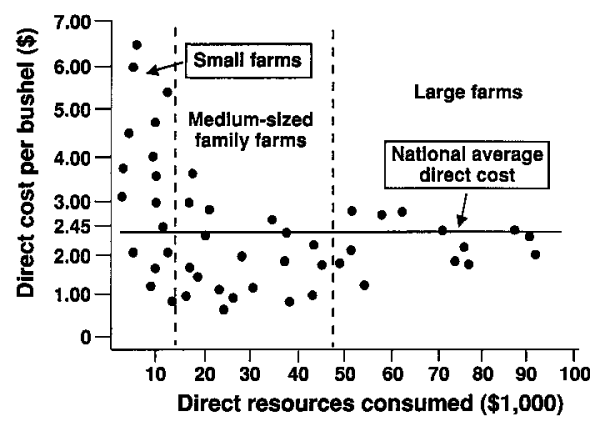

Fig. 2. Efficiency of farm size measured by resources consumed. Each point represents one wheat farm, 1978. (Source: Based on data from Miller, 1979, used in figure 4 of Strange, Family Farming, 1988.)

TABLE 3. Major differences in economic structure of large- and small-farm counties

\begin{tabular}{|c|c|c|c|}
\hline Item & Unit & $\begin{array}{c}\text { Large- } \\
\text { farm } \\
\text { counties }\end{array}$ & $\begin{array}{c}\text { Small- } \\
\text { farm } \\
\text { counties }\end{array}$ \\
\hline \multicolumn{4}{|l|}{ Average: } \\
\hline Total employment, 1982 & no. & 13,947 & 29,077 \\
\hline Nonfarm employment, 1982 & no. & 12,356 & 28,179 \\
\hline Manufacturing industries & no. & 2,133 & 4,818 \\
\hline Service-producing industries ${ }^{*}$ & no. & 5,322 & 12,368 \\
\hline Government & no. & 2,389 & 5,309 \\
\hline Total employment, 1975 & no. & 12,701 & 23,878 \\
\hline Nonfarm employment, 1975 & no. & 11,005 & 22,934 \\
\hline Manufacturing industries & no. & 2,107 & 4,487 \\
\hline Service-producing industries* & no. & 4,429 & 9,251 \\
\hline Government & no. & 2,363 & 4,760 \\
\hline \multicolumn{4}{|l|}{ Change from $1975-82$ in: } \\
\hline Total employment & $\%$ & 6.1 & 17.4 \\
\hline Nonfarm employment & $\%$ & 10.2 & 20.8 \\
\hline Manufacturing employment & $\%$ & 23.6 & 22.7 \\
\hline Service employment & $\%$ & 12.9 & 28.1 \\
\hline \multicolumn{4}{|l|}{ Total labor and proprietor income, } \\
\hline \multicolumn{4}{|l|}{ Amount derived from: } \\
\hline Farming & $\%$ & 21.0 & 4.3 \\
\hline Manufacturing industries & $\%$ & 15.1 & 23.5 \\
\hline Service-producing industries* & $\%$ & 31.0 & 29.2 \\
\hline Per capita personal income, 1982 & $\$$ & 9,807 & 8,261 \\
\hline Per capita transfer payments, 1982 & $\$$ & 1,505 & 1,560 \\
\hline
\end{tabular}

Data show average per county.

"Includes wholesale and retail trade; finance, insurance, and real estate; and personal business service firms. Source: Carlin and Green, Rural Development Perspectives, table 3, 1989.

Other studies suggest that a poor quality of life, as indicated by poverty, hunger and undereducation, tends to be higher in large-farm areas than in those with a smaller, more diverse farm structure. One study of rural communities in 200 agricultural counties across the U.S. analyzed the correlation between poverty and agriculture and found that the poverty rate grew with increases in farm size, and that the faster the rate at which farms increased in size, the faster the rate at which poverty increased. This was because household incomes tended to be more polarized in large-farm counties, and farm labor households tend to earn low incomes.

Small farmers have been early adopters of many innovative farming systems and practices, including contour plowing and the use of cover crops for erosion control, and low-input production regimes. In this respect, they have served as pathfinders for large-scale farmers. In the early $1980 \mathrm{~s}$ one was not likely to find high-volume corporate growers at the Ecological Farming Conference. It is no longer unusual.

As organic farming has become more practical and less risky, there has been a dramatic rise in the average acreage of the California Certified Organic Growers (see table 4). The average acreage per certified organic grower in 1986 was only 29 acres. By 1992, the average per grower had climbed to 104 acres - an increase of $259 \%$.

California's experience also indicates that small farmers are willing to experiment with relatively obscure seed and plant varieties; they have brought back to consumers' tables a remarkable variety of products, diversifying American diets and heightening interest in nutrition and health. They have also contributed significantly to biological diversity, increasingly recognized as essential to ecological stability.

\section{Policy implications}

Less than two decades ago, a study on small farm viability was submitted to the state of California. The report, The Family Farm in California, observed, "The evidence suggests that judicious encouragement of viable family farms will improve the overall productiveness and competitiveness of California agriculture, not impair it." Furthermore, it noted, "Public policy has played a major role in reducing competitiveness, and public policy can be used to increase it." Along that line, it implied that a reevaluation of federal reclamation policy might be in order to increase small farm access to irrigated farmland. Other important conclusions were that:

"There is no one best way to farm; agricultural practices always are devel- 


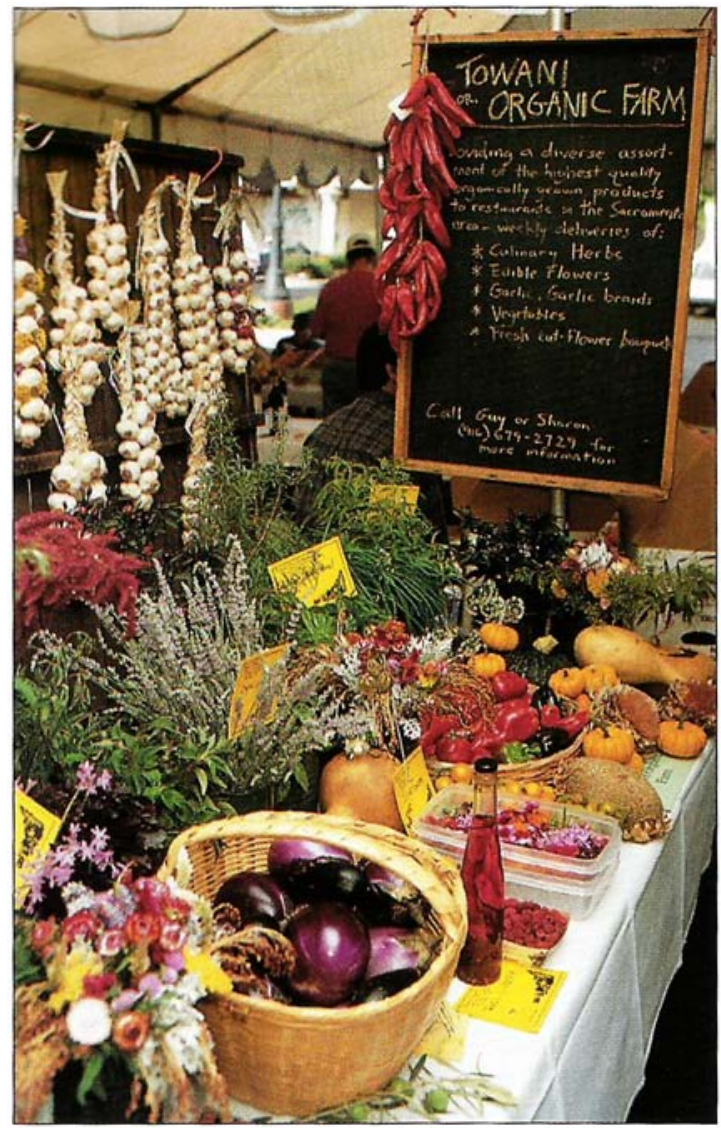

Organic produce displayed by one small farmer at the Sacramento Summer Harvest Tasting in September, 1992.

oped to meet specific conditions. A policy to promote the family farm implies that, over time, it will be necessary to evolve production and marketing systems that will reinforce the competitive position of the smaller farm unit. Through the university system, the taxpayer dollar already supports what many feel to be the best agricultural research and extension capability in the nation. Its ingenuity in helping shape an agriculture well adapted to large farms bespeaks ample talent that could and should now be turned to creating an equally sophisticated agriculture adapted to family farms. By way of example, this might mean development of smaller and more versatile farm equipment, cropping systems permitting practical diversification on smaller acreages, and innovations in delivering extension services to larger numbers of family farmers.

Family farmers, who are a majority of all California farmers, need to have more voice in developing programs and regulations that affect them. That is why the Marketing Task Force, for example, suggests establishment of an unpaid board composed only of family farmers to review marketing rules and regulations for unnecessary bias against smaller producers.
Marketing is at present the single most limiting constraint on the operators of small farms. Many farmers could grow certain crops which they do not, simply because markets for small producers are particularly limited, uncertain, or unknown. Vegetables, which can be profitably raised in small volumes but tend to be contracted in large volumes, are a case in point. Many state rules and regulations governing the marketing system ignore the needs of relatively small producers. Most importantly, the marketing system does not reward the family farmer for what he can do most competitively, which is to provide the market with a product of particularly high quality. The state has much to do with the structure and operation of the marketing system, and it can be helpful in making a more tenable place for the small farmer in it."

It was recommended that the state (1) actively maintain the competitive position of the family farmer and facilitate the entry of new farmers; (2) discourage any concentration of economic control over agricultural resources and markets that diminishes the family farmer's competitive position and impedes entry of new farmers, (3) promote a family farm policy that would be part of a more general commitment to developing strong rural communities, and (4) charter a nonprofit corporation to encourage and assist local rural development, including the formation of family farms.

It was also recommended that the state of California establish rural oversight committees in the houses of the Legislature or a joint committee; establish in the executive branch a capacity for identifying and analyzing rural and agricultural issues; improve coordination of state programs serving rural areas, and establish closer working relationships with federal programs.

\section{Conclusions and implications}

California has gone a long way towards recognizing the contributions of

\begin{tabular}{|cccc|}
\hline $\begin{array}{c}\text { TABLE } \\
\text { 4. Total number of growers, acres and } \\
\text { average organic acreage in California }\end{array}$ \\
\hline Year & $\begin{array}{c}\text { Certified } \\
\text { growers }\end{array}$ & $\begin{array}{c}\text { Certified } \\
\text { acreage }\end{array}$ & $\begin{array}{c}\text { Average acreage } \\
\text { per grower }\end{array}$ \\
\hline & $n o$. & $\ldots \ldots \ldots \ldots . . . . . . . . .$. \\
1986 & 164 & 4,800 & 29.27 \\
1987 & 191 & 7,470 & 39.11 \\
1988 & 244 & 16,755 & 68.67 \\
1989 & 298 & 22,240 & 74.63 \\
1990 & 349 & 36,310 & 104.04 \\
1991 & 395 & 39,611 & 100.28 \\
1992 & 493 & 51,508 & 104.48 \\
\hline Source: California Certified Organic Growers.
\end{tabular}

small, family farms in its economy, but the job is not finished. The University of California supports a cadre of small farm extension agents as well as the Small Farm Center at UC Davis. The state, working with UC, has established a Sustainable Agriculture Research and Education Program on alternative agricultural practices that are ecologically sound as well as economically rational and socially responsible. The Direct Marketing Program, stimulated initially by the California Department of Food and Agriculture, improved marketing access for smaller scale growers. Though now disbanded, the program provided oversight, technical assistance and other services to maintain and further develop farmers' markets. The Governor's Task Force on Rural Development is currently conducting hearings throughout California on the status of, and prospects for, economic and social development in rural California.

Private groups, such as the California Association of Family Farmers, which coorganizes the annual Family Farm Conference, and the Committee for Sustainable Agriculture, which organizes the annual Ecological Farming Conference and conducts transitional farming workshops, have assisted the performance of the small farm sector. Additionally, the development of California cuisine has created a new market for specialty products - including radicchio, arugula, edible flowers and sun-dried tomatoes. Specialty crop production is the kind in which smallscale operations often hold a distinct advantage.

But whereas the study on small farm viability in 1977 identified marketing as the area of greatest constraint for small farmers, the biggest constraint today may be diminished access to credit (see p. 23). Bank failures and the increasingly conservative, risk-averse position of financial institutions have generated evaluation criteria and loan decisions unfriendly to family farmers.

It has become apparent, however, that family-sized operations can, and often do, operate efficiently. Furthermore, they generate social benefits to our society.

Whether they continue to make these contributions depends, partly, on how public policy and public institutions respond, particularly during the changes in trade on the North American continent and in the rest of the world. In all likelihood, small farms will continue to be a dynamic source for innovation and socio-economic stability.

D. A. Jolly is Extension Economist, Department of Agricultural Economics, UC Davis. 